\title{
PEMETAAN RISIKO IKLIM SEBAGAI HASIL PERUMUSAN AKSI ADAPTASI PERUBAHAN IKLIM KABUPATEN PROBOLINGGO
}

\author{
Amien Widodo ${ }^{1)}$, Wien Lestari ${ }^{1)}$, Adjie Pamungkas ${ }^{2)}$, Ketut Dewi Martha Erly ${ }^{2)}$, \\ Ummi Fadlilah K. ${ }^{2)}$, Nurlaili Humaidah ${ }^{3)}$ \\ ${ }^{1)}$ Teknik Geofisika, ITS, ${ }^{2)}$ Perencanaan Wilayah dan Kota, ITS, ${ }^{3)}$ Teknik Kimia, ITS \\ e-mail:pskbpi.cc@gmail.com
}

\begin{abstract}
Abstrak. Kabupaten Probolinggo sebagai salah satu kabupaten yang memiliki peran strategis dalam pengembangan wilayah Jawa Timur mulai merasakan adanya gejala-gejala perubahan iklim, seperti kenaikan muka air laut, cuaca ekstrim, kenaikan suhu udara, dan perubahan pola curah hujan. Dampak perubahan iklim ini mengakibatkan permasalahan pada sektor air bersih, kekeringan, banjir, peningkatan wabah penyakit, dan sebagainya. Kegiatan ini difokuskan kepada strategi dan rencana aksi adaptasi dampak perubahan iklim di kabupaten Probolinggo. Tindakan adaptasi adalah penyesuaian pada sistem alam dan sistem kehidupan manusia dalam merespon risiko dan peluang yang timbul dari perubahan iklim yang tidak dapat dihindari. Kegiatan ini bertujuan untuk mendapatkan profil risiko iklim terhadap sistem kota/kabupaten yang rapuh dan terpengaruh dari dampak perubahan iklim di Kabupaten Probolinggo. Strategi dan rencana aksi adaptasi Kabupaten Probolinggo dilakukan dalam beberapa tahapan yaitu identifikasi dampak dari fenomena perubahan iklim, penentuan sistem kota yang rapuh, dan pemetaan risiko iklim tiap kecamatan menggunakan software ArcGIS berdasarkan skala kemungkinan dan skala konsekuensi dampak perubahan iklim terhadap sistem kota.
\end{abstract}

Kata Kunci: adaptasi, perubahan iklim, peta kerentanan, Kabupaten Probolinggo.

Abstract. Probolinggo, a district that has strategic roles in a development of East Java, is starting to feel the indication of climate change such as sea level rise, extremely weather change, temperature rise, and rainfall pattern change. Those indication of climate change give some negative impacts to the environment such as lack of clean water, drought, flood, disease potential, and some else. Therefore, this activity focuses to make some strategies and plans about adaptation of climate change impact in Probolinggo by having a good adaptation with nature and human living system there. It is a strategy to respond the risks and chances of unavoidable climate change. The aim of this activity is to know the climate risk profile of an unstable city system due to the climate change impact in Probolinggo. The activity consists of climate change impact identification, unstable city system determination, climate risk mapping in each District with ArcGIS based on the probability scale and consequent scale of climate change impact to the city system.

Keywords: adaption, climate change, fragility map, Probolinggo.

\section{PENDAHULUAN}

\section{Latar Belakang}

Kabupaten Probolinggo merupakan salah satu

kabupaten di Provinsi Jawa Timur yang akhir-akhir ini terus berkembang pesat sejalan dengan perkembangan dan perubahan sosial, budaya, ekonomi, dan politiknya. Pertumbuhan ekonomi ini terus mengalami peningkatan dari tahun sebelumnya. Di lain pihak, pertumbuhan ekonomi tersebut diikuti oleh pertumbuhan emisi Gas Rumah Kaca (GRK) akibat aktivitas pembangunan. Hal inilah yang memicu peningkatan dampak perubahan iklim yang dirasakan Kabupaten Probolinggo. Komitmen
Indonesia untuk mengurangi emisi Gas Rumah Kaca (mitigasi) dan penyesuaian pada sistem alam dan sistem kehidupan manusia dalam merespon risiko dan peluang yang timbul dari perubahan iklim (adaptasi) diperkuat dalam keputusan presiden yang harus dilaksanakan oleh pemerintah pusat hingga daerah kabupaten/kota. Formulasi kebijakan dan strategi mengenai upaya adaptasi terhadap perubahan iklim tertuang dalam Rencana Aksi Nasional Adaptasi Perubahan Iklim (RAN-API). RANAPI ini memuat strategi pembangunan dan rencana-rencana aksi yang menjamin adanya 
ketahanan terhadap perubahan iklim (Bappenas, 2012).

Studi yang dibahas dalam paper ini hanya membahas aksi adaptasi perubahan iklim Kabupaten Probolinggo. Tujuan dari studi ini adalah untuk mendapatkan profil risiko iklim dengan mempertimbangkan skala kemungkinan dan skala konsekuensi terhadap sistem kota/kabupaten yang rapuh dan terpengaruh oleh dampak perubahan iklim di Kabupaten Probolinggo. Comhshaol dan Áitiúl (2012) menjelaskan banyak langkah adaptasi sampai saat ini yang hanya bersifat reaktif, langsung dibawa untuk menanggapi peristiwa cuaca ekstrim yang telah terjadi dan dampaknya. Akan tetapi, untuk saat ini perlu pengembangan adaptasi dengan pendekatan yang terencana atau direncanakan sebagai hasil kebijakan yang disengaja berdasarkan kesadaran bahwa kondisi telah berubah atau yang diprediksikan berubah.

\section{METODOLOGI}

\section{Identifikasi Dampak Perubahan Iklim di Kabupaten Probolinggo}

Proses identifikasi dampak perubahan iklim dilaksanakan dalam bentuk lokakarya pegawaipegawai pemerintahan yang tergabung dalam kelompok kerja (pokja) perubahan iklim Kabupaten Probolinggo berdasarkan data-data yang terdapat di kantor masing-masing. Proses identifikasi dilaksanakan dalam beberapa tahapan yang akan dijabarkan sebagai berikut:

a. Identifikasi awal untuk dampak perubahan iklim di Kabupaten Probolinggo dalam bentuk lokakarya 1. Kegiatan di lokakarya 1 adalah setiap SKPD yang tergabung dalam pokja perubahan iklim Kabupaten Probolinggo mengisi Tabel pemetaan dampak fenomena perubahan iklim yang dialami oleh Kabupaten Probolinggo berdasarkan data yang terdapat di SKPD yang selanjutnya dibahas bersama. Hasil diskusi menghasilkan pemetaan daerah berdasarkan dampak perubahan iklim di Kabupaten Probolinggo, antara lain:
- Kenaikan permukaan air laut mengakibatkan terjadinya banjir rob dan abrasi.

- Banjir rob sering terjadi di Kecamatan Kraksaan dan Paiton, khususnya di Desa Tongas, Sumber Asih, Dringu, Gending, dan Pajaek. Waktu kejadiannya biasanya terjadi pada bulan Januari-Maret dari tahun 2000- sekarang. Tinggi banjir rob bisa mencapai 1 meter lebih.

- Abrasi sering terjadi di Kecamatan Gending, Paiton, dan Kraksaan.

- Perubahan curah hujan menyebabkan kekeringan, banjir, longsor, dan DBD.

- Kekeringan terjadi di Kecamatan Wonomerto, Kuripan, Tongas, Bantaran, Sukapura, Tegalsiwalan, dan Banyuanyar. Waktu terjadinya yaitu Maret-Nopember 2013. Kekeringan berdampak pada multi sektor di Kabupaten Probolinggo diantaranya krisis air bersih, gagal panen, dan menurunnya produksi garam.

- Banjir sering terjadi di Kecamatan Kuripan, Bantaran, Sumberasih, Dringu, Gending, Paiton, Pakuningan, Kotaanyar, dan Kraksaan. Waktu terjadinya belum lama ini sekitar Desember 2013 sampai Februari 2014.

- Dampak longsor biasanya terjadi di Kecamatan Tiris, Sumber, dan Sukapura pada bulan Desember sampai Februari dan diperkirakan akan terjadi tahunan.

- Penyakit demam berdarah terjadi di kecamatan-kecamatan di pesisir, yaitu Kecamatan Paiton, Kraksaan, Maron, Sumberasih, Gending, Leces, Banyuanyar, Tegalsiwalan, Tongas, Dringu, dan Besuk. Waktu terjadinya pada saat musim hujan berlangsung. Diperkirakan akan terjadi lima tahunan pada masa yang akan datang.

- Kenaikan suhu udara menyebabkan terjadinya wabah penyakit chikungunya dan krisis air bersih. 
- Penyakit chikunguya mewabah di Kecamatan Maron dan Gending. Waktu terjadinya sekitar awal 2014 dan menurut pemerintah Kabupaten Probolinggo diperkirakan akan terjadi tiap tahun.

- Kekurangan air bersih terjadi di 14 kecamatan di Kabupaten Probolinggo, yaitu Kecamatan Tongas, Sukapura, Lumbang, Sumber, Kuripan, Krucil, Kotaanyar, Paiton, Tegalsiwalan, Tiris, Pakuniran, dan Wonomerto.

- Cuaca Ekstrim menyebabkan terjadinya badai/angin kencang dan angin puting beliung.

- Badai atau angin kencang terjadi di kecamatan-kecamatan yang berada di wilayah pantai utara di Kabupaten Probolinggo, khususnya Kecamatan Sumber dan Maron. Waktu terjadinya sekitar bulan Juli-Agustus.

- Angin puting beliung terjadi di Kecamatan Tongas, Lumbang, Krucil, dan Paiton. Waktu terjadinya sekitar tahun 2002, 2008, 2009, dan 2013. Dampak dari angin puting beliung dan angin kencang ini, antara lain rusaknya rumah, infrastruktur, dan masyarakat pun rugi secara materi.

b. Tahap kedua adalah verifikasi keterkaitan kejadian yang diidentifikasi dengan data sekunder dan informasi yang ada dari instansi terkait, seperti BPBD, dinas kesehatan, dan dinas PU Pengairan sehingga dapat diketahui akumulatif dampak dari fenomena perubahan iklim yang terjadi, kerugian yang dialami, jumlah penderita, dan keadaan iklim pada saat dampak fenomena tersebut terjadi.

c. Tahap ketiga adalah identifikasi sistem kota/kabupaten yang rapuh yang terjadi di Kabupaten Probolinggo didasarkan pada dampak perubahan iklim yang terjadi. Hal yang harus dilakukan partisipan selanjutnya adalah memilih skala kemungkinan dan skala konsekuensi yang paling sesuai untuk setiap dampak dan seberapa kemungkinan dampak perubahan iklim tersebut terjadi lagi pada masa yang akan datang dan dengan mempertimbangkan data historis kejadian tersebut. Hasil diskusi diperlihatkan pada Tabel 1 berikut.

Tabel 1. Skala Kemungkinan dan Konsekuensi Perubahan Iklim Kabupaten Sidoarjo

\begin{tabular}{|c|c|c|c|c|}
\hline Fenomena & $\begin{array}{l}\text { Dampak } \\
\text { Perubahan } \\
\text { Iklim }\end{array}$ & $\begin{array}{l}\text { Sistem Kota } \\
\text { yang } \\
\text { terpengaruh }\end{array}$ & $\begin{array}{l}\text { Hasil Skala } \\
\text { Kemung- } \\
\text { kinan }\end{array}$ & $\begin{array}{l}\text { Hasil Skala } \\
\text { Konse- } \\
\text { kuensi }\end{array}$ \\
\hline \multirow{3}{*}{$\begin{array}{l}\text { Kenaikan } \\
\text { muka air } \\
\text { laut }\end{array}$} & Banjir rob & $\begin{array}{c}\text { Sistem } \\
\text { pertanian }\end{array}$ & $\begin{array}{c}2 \\
\text { (mungkin) }\end{array}$ & $\begin{array}{c}2 \\
\text { (sedang) }\end{array}$ \\
\hline & \multirow[t]{2}{*}{$\begin{array}{l}\text { Abrasi } \\
\text { pantai }\end{array}$} & $\begin{array}{c}\text { Lahan } \\
\text { tambak }\end{array}$ & $\begin{array}{c}2 \\
\text { (mungkin) }\end{array}$ & $\begin{array}{c}2 \\
\text { (sedang) }\end{array}$ \\
\hline & & Transportasi & $\begin{array}{c}2 \\
\text { (mungkin) }\end{array}$ & $\begin{array}{c}2 \\
\text { (sedang) }\end{array}$ \\
\hline \multirow[t]{5}{*}{$\begin{array}{c}\text { Perubah- } \\
\text { an curah } \\
\text { hujan }\end{array}$} & $\begin{array}{c}\text { Kekering- } \\
\text { an }\end{array}$ & $\begin{array}{l}\text { Sistem } \\
\text { penyediaan } \\
\text { air bersih }\end{array}$ & $\begin{array}{c}2 \\
\text { (mungkin) }\end{array}$ & $\begin{array}{c}2 \\
\text { (sedang) }\end{array}$ \\
\hline & Banjir & $\begin{array}{c}\text { Sistem } \\
\text { drainase }\end{array}$ & $\begin{array}{c}3 \\
\text { (sangat } \\
\text { mungkin) }\end{array}$ & $\begin{array}{c}3 \\
\text { (tinggi) }\end{array}$ \\
\hline & Longsor & $\begin{array}{c}\text { Lahan } \\
\text { pertanian dan } \\
\text { hutan }\end{array}$ & $\begin{array}{c}4 \\
\text { (hampir } \\
\text { pasti) }\end{array}$ & $\begin{array}{c}3 \\
\text { (tinggi) }\end{array}$ \\
\hline & & Infrastruktur & $\begin{array}{c}3 \\
\text { (sangat } \\
\text { mungkin) }\end{array}$ & $\begin{array}{c}4 \\
\text { (ekstrim) }\end{array}$ \\
\hline & $\begin{array}{c}\text { Demam } \\
\text { berdarah }\end{array}$ & $\begin{array}{c}\text { Sistem } \\
\text { kesehatan }\end{array}$ & $\begin{array}{c}4 \\
\text { (hampir } \\
\text { pasti) }\end{array}$ & $\begin{array}{c}4 \\
\text { (ekstrim) }\end{array}$ \\
\hline \multirow[t]{2}{*}{$\begin{array}{l}\text { Perubah- } \\
\text { an suhu }\end{array}$} & $\begin{array}{c}\text { Penyakit } \\
\text { chikungu- } \\
\text { nya }\end{array}$ & $\begin{array}{c}\text { Sistem } \\
\text { pendidikan, } \\
\text { kesehatan, } \\
\text { dan ekonomi }\end{array}$ & $\begin{array}{c}3 \\
\text { (sangat } \\
\text { mungkin) }\end{array}$ & $\begin{array}{c}3 \\
\text { (tinggi) }\end{array}$ \\
\hline & $\begin{array}{c}\text { Kekurang } \\
\text { an air } \\
\text { bersih }\end{array}$ & $\begin{array}{c}\text { Sistem } \\
\text { kesehatan }\end{array}$ & $\begin{array}{c}2 \\
\text { (mungkin) }\end{array}$ & $\begin{array}{c}2 \\
\text { (sedang) }\end{array}$ \\
\hline \multirow[t]{4}{*}{$\begin{array}{c}\text { Cuaca } \\
\text { ekstrim }\end{array}$} & \multirow[t]{2}{*}{$\begin{array}{l}\text { Badai/ } \\
\text { angin } \\
\text { kencang }\end{array}$} & $\begin{array}{c}\text { Sistem } \\
\text { pemukiman }\end{array}$ & $\begin{array}{c}4 \\
\text { (hampir } \\
\text { pasti) }\end{array}$ & $\begin{array}{c}2 \\
\text { (sedang) }\end{array}$ \\
\hline & & $\begin{array}{c}\text { Sistem } \\
\text { ketahanan } \\
\text { pangan }\end{array}$ & $\begin{array}{c}4 \\
\text { (hampir } \\
\text { pasti) }\end{array}$ & $\begin{array}{c}3 \\
\text { (tinggi) }\end{array}$ \\
\hline & \multirow[t]{2}{*}{$\begin{array}{l}\text { Angin } \\
\text { Puting } \\
\text { Beliung }\end{array}$} & $\begin{array}{c}\text { Sistem } \\
\text { pemukiman }\end{array}$ & $\begin{array}{c}4 \\
\text { (hampir } \\
\text { pasti) }\end{array}$ & $\begin{array}{c}3 \\
\text { (tinggi) }\end{array}$ \\
\hline & & $\begin{array}{c}\text { Sistem } \\
\text { ketahanan } \\
\text { pangan }\end{array}$ & $\begin{array}{c}4 \\
\text { (hampir } \\
\text { pasti) }\end{array}$ & $\begin{array}{c}4 \\
\text { (ekstrim) }\end{array}$ \\
\hline
\end{tabular}

d. Tahap keempat adalah scoring atau penilaian tingkat risiko setiap dampak perubahan iklim yang terjadi di Kabupaten Probolinggo dengan mengalikan hasil skala kemungkinan dan konsekuensi tiap dampak perubahan iklim yang 
terjadi. Hasil scoring kedua skala tersebut diberikan pada Tabel 2 di bawah ini.

Tabel 2. Tingkat Risiko dan Rangking dari Dampak Perubahan Iklim yang Terjadi di Kabupaten Probolinggo

\begin{tabular}{|c|c|c|c|c|}
\hline $\begin{array}{l}\text { Feno } \\
\text { mena }\end{array}$ & $\begin{array}{l}\text { Dampak } \\
\text { Perubahan } \\
\text { Iklim }\end{array}$ & $\begin{array}{l}\text { Sistem Kota } \\
\text { yang } \\
\text { terpengaruh }\end{array}$ & $\begin{array}{l}\text { Tingkat } \\
\text { Risiko } \\
\text { (H) }\end{array}$ & Rank \\
\hline \multirow{3}{*}{$\begin{array}{l}\text { Kenaik } \\
\text { an } \\
\text { muka } \\
\text { air laut }\end{array}$} & Banjir rob & $\begin{array}{l}\text { Sistem } \\
\text { pertanian }\end{array}$ & $\begin{array}{l}4 \\
\text { (rendah) }\end{array}$ & 10 \\
\hline & \multirow[t]{2}{*}{$\begin{array}{l}\text { Abrasi } \\
\text { pantai }\end{array}$} & Lahan tambak & $\begin{array}{l}4 \\
\text { (rendah) }\end{array}$ & 11 \\
\hline & & Transportasi & $\begin{array}{l}4 \\
\text { (rendah) }\end{array}$ & 12 \\
\hline \multirow{5}{*}{$\begin{array}{l}\text { Peru- } \\
\text { bahan } \\
\text { curah } \\
\text { hujan }\end{array}$} & Kekeringan & $\begin{array}{l}\text { Sistem } \\
\text { penyediaan air } \\
\text { bersih }\end{array}$ & $\begin{array}{l}4 \\
\text { (rendah) }\end{array}$ & 13 \\
\hline & Banjir & $\begin{array}{l}\text { Sistem } \\
\text { drainase }\end{array}$ & $\begin{array}{l}9 \\
\text { (sedang) }\end{array}$ & 7 \\
\hline & \multirow[t]{2}{*}{ Longsor } & $\begin{array}{l}\text { Lahan } \\
\text { pertanian dan } \\
\text { hutan }\end{array}$ & $\begin{array}{l}12 \\
\text { (tinggi) }\end{array}$ & 3 \\
\hline & & Infrastruktur & $\begin{array}{l}12 \\
\text { (tinggi) }\end{array}$ & 4 \\
\hline & $\begin{array}{l}\text { Demam } \\
\text { berdarah }\end{array}$ & $\begin{array}{l}\text { Sistem } \\
\text { kesehatan }\end{array}$ & $\begin{array}{l}16 \\
\text { (tinggi) }\end{array}$ & 1 \\
\hline \multirow[t]{2}{*}{$\begin{array}{l}\text { Peru } \\
\text { bahan } \\
\text { suhu }\end{array}$} & $\begin{array}{l}\text { Penyakit } \\
\text { chikungu- } \\
\text { nya }\end{array}$ & $\begin{array}{l}\text { Sistem } \\
\text { pendidikan, } \\
\text { kesehatan, } \\
\text { dan ekonomi }\end{array}$ & $\begin{array}{l}9 \\
\text { (sedang) }\end{array}$ & 8 \\
\hline & $\begin{array}{l}\text { Kekurangan } \\
\text { air bersih }\end{array}$ & $\begin{array}{l}\text { Sistem } \\
\text { kesehatan }\end{array}$ & $\begin{array}{l}4 \\
\text { (rendah) }\end{array}$ & 14 \\
\hline \multirow[t]{4}{*}{$\begin{array}{l}\text { Cuaca } \\
\text { ekstrim }\end{array}$} & \multirow[t]{2}{*}{$\begin{array}{l}\text { Badai/angin } \\
\text { kencang }\end{array}$} & $\begin{array}{l}\text { Sistem } \\
\text { pemukiman }\end{array}$ & $\begin{array}{l}8 \\
\text { (sedang) }\end{array}$ & 9 \\
\hline & & $\begin{array}{l}\text { Sistem } \\
\text { ketahanan } \\
\text { pangan }\end{array}$ & $\begin{array}{l}12 \\
\text { (tinggi) }\end{array}$ & 5 \\
\hline & \multirow{2}{*}{$\begin{array}{l}\text { Angin } \\
\text { Puting } \\
\text { Beliung }\end{array}$} & $\begin{array}{l}\text { Sistem } \\
\text { pemukiman }\end{array}$ & $\begin{array}{l}12 \\
\text { (tinggi) }\end{array}$ & 6 \\
\hline & & $\begin{array}{l}\text { Sistem } \\
\text { ketahanan } \\
\text { pangan }\end{array}$ & $\begin{array}{l}16 \\
\text { (tinggi) }\end{array}$ & 2 \\
\hline
\end{tabular}

Berdasarkan tabel di atas, dapat dilihat bahwa prioritas penanganan dampak menurut tingkat risikonya di Kabupaten Probolinggo adalah sebagai berikut.

- Prioritas 1 dengan nilai risiko iklim tinggi, yaitu:

- Deman berdarah yang mempengaruhi sistem kesehatan.

- Angin puting beliung yang mempengaruhi sistem permukiman dan ketahanan pangan.
- Badai atau angin kencang yang mempengaruhi sistem ketahanan pangan.

- Longsor yang mempengaruhi lahan pertanian, hutan, dan infrastruktur.

- Prioritas 2 dengan nilai risiko iklim sedang, yaitu:

- Banjir yang mempengaruhi sistem drainase.

- Penyakit chikungunya yang mempengaruhi sistem pendidikan, kesehatan, dan ekonomi.

- Prioritas 3 dengan nilai risiko iklim rendah, yaitu:

- Banjir rob yang mempengaruhi sistem lahan pertanian.

- Abrasi pantai yang mempengaruhi lahan tambak dan transportasi.

- Kekeringan yang mempengaruhi sistem penyediaan air.

- Kekurangan air bersih yang mempengaruhi sistem kesehatan.

e. Tahap terakhir adalah pemetaan kerentanan perubahan iklim yang terjadi di Kabupaten Probolinggo menggunakan software ArcGIS berdasarkan prioritas atau hasil dari tingkat risiko dampak perubahan iklim yang masuk dalam kategori tinggi, sedang, dan rendah.

\section{HASIL DAN PEMBAHASAN}

Gambar 1 memperlihatkan peta kerentanan keseluruhan level prioritas risiko dampak perubahan iklim di Kabupaten Probolinggo.

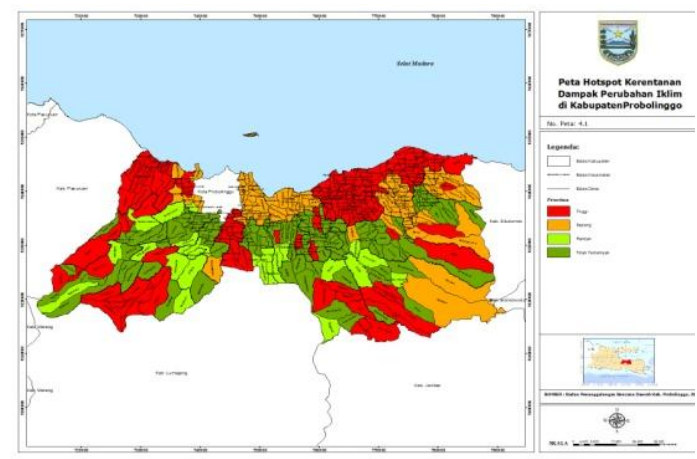

Gambar 1. Pemetaan Keseluruhan Dampak Perubahan Iklim dari Prioritas 1 


\section{Pemetaan Dampak Perubahan Iklim dari Prioritas 1}

Pemetaan dampak perubahan iklim dari prioritas 1 terdiri dari pemetaan dampak dari perubahan iklim, seperti: demam berdarah, angin puting beliung, angin kencang, dan longsor. Dengan wilayah terdampak sebagai berikut:

- Longsor terjadi di Kecamatan Tongas (Desa Tanjung Rejo); Kecamatan Tiris (Desa Andung Biru, Segaran, Jangkang, Ranugedang, dan Tlogo Argo); Kecamatan Sumberasih (Desa Mentor); Kecamatan Sumber (Desa Tukul, Pandansari, Sumberanom, Gemito, dan Wonokerso); Kecamatan Sukapura (Desa Ngadisari); Kecamatan Pajarakan (Desa Pajarakan Kulon); Kecamatan Paiton (Desa Petunjungan); Kecamatan Lumbag (Desa Sapih); Kecamatan Leces (Desa Jorongan); Kecamatan Kuripan (Desa Resongo); Kecamatan Krucil (Desa Roto, Tambelang, Krucil, danKertosuko); Kecamatan Kraksaan (Kelurahan Sidomukti); dan Kecamatan Banyuanyar (Desa Klenang Kidul).

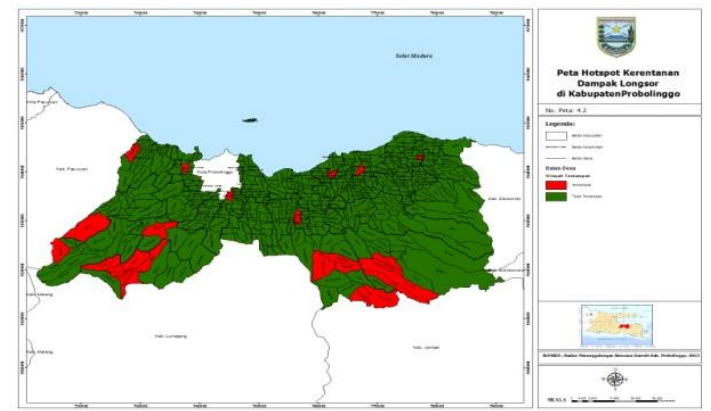

Gambar 2. Pemetaan Dampak Perubahan Iklim Longsor Prioritas 1

- Angin puting beliung, terjadi di Kecamatan Gading (Desa Batur, Prasi, dan Klaseman); Kecamatan Krejengan (Desa Sokaan, Sentong, Sumberkatimoho, dan Krejengan); Kecamatan Lumbang (Desa Purut, Lumbang, dan Branggah); Kecamatan Maron (Desa Ganting Wetandan Suko); Kecamatan Paiton (Desa Sumberejo, Sidodadi, Alas Tengah, dan Sumberanyar); Kecamatan Sukapura (Desa Ngadisari, Sapikerep, dan Jetak); Kecamatan Sumber (Desa Sumber, Sumberanom, Gemito, Wonokerso, dan Ledokombo); Kecamatan Sumberasih (Desa
Ambulu, jangur, Sumurmati, Mentor, dan Lemah Kembar); Kecamatan Tiris (Desa Tiris, dan Jangkang); dan Kecamatan Tongas (Desa Tanjung Rejo).

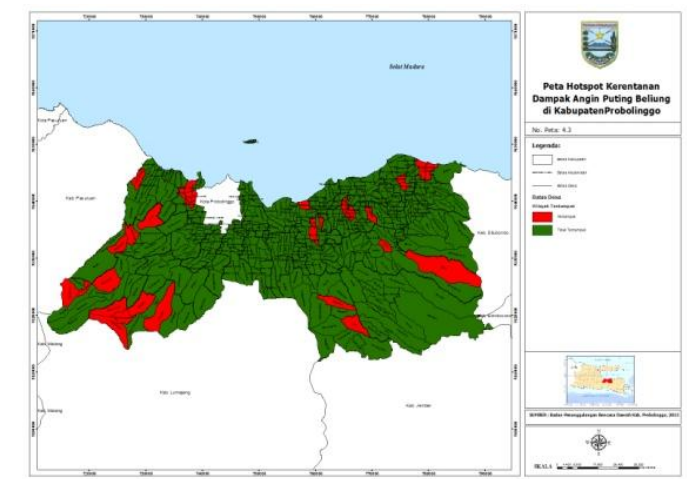

Gambar 3. Pemetaan Dampak Perubahan Iklim Angin Putting Beliung Prioritas 1

- Deman berdarah (DBD) terjadi di Kecamatan Kraksaan (Desa Kalibuntu, Kebonagung, Kandangjati Wetan, Rangkang, Rondokuning, Asembagus, Kelurahan Kraksaan Wetan, Patokan, Sidopekso, Sidumukti, Kegenan, Semampir, dan Desa Bulu); Kecamatan Krejengan (Desa Opo-Opo, Sokaan, Petemon, Temanggungan, Widoro, Sentong, Sumberkatimoho, Karangren, Kedung Caluk, Dawuhan, Seboroh, Gebangan Jatiurip, Kamalkuning, Krejengan, Tanjungsari, dan Waran); Kecamatan Leces (Warungjinggo, Jorongan, Malasan, Kulon, Clarak, Kerpangan, Sumberkedawung, Tigasan Wetan, Leces, Tigasan Kulon, dan Pondokwuluh); Kecamatan Paiton (Desa Jabung Sisir, Randu Tatah, Sumberejo, Sidodadi, Alas Tengah, Pondo Kelor, Sumberanyar, Jabung Candi, Taman, Paiton, Pandean, Petunjungan, Bhinor, Kalijajar Wetan, Plampang, Karanganyar, Kalijajar Kulon, Randu Merak, Jabung Wetan, dan Sukodadi); Kecamatan Pajarakan (Desa Tanjung, Karangpranti, Gejukan, Selogudig Wetan, Ketompen, Karangbong, Pajarakan Kulon, Selogudig Kulon, Sukomulyo, Karang Geger, Penambangan, dan Sukokerto ); Kec Tongas (Bayeman, Tongas, Kulon, Curah Tulis, Sumberejo, Wringinanom, Pamatan, Klampok, 
Tanjungrejo, Tambakrejo, Sumber Kramat, Sumendi, Tongas Wetan, dan Desa Dungun).

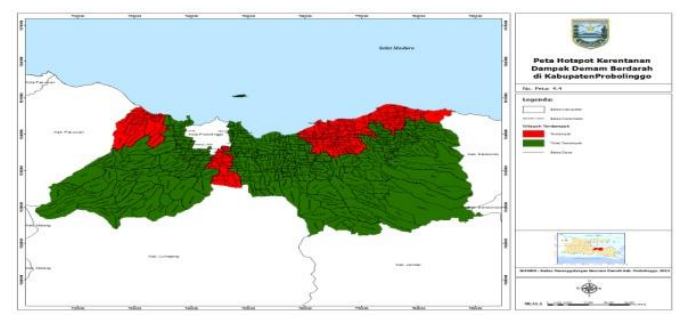

Gambar 4. Pemetaan Dampak Perubahan Iklim Demam Berdarah Prioritas 1

- Angin kencang, terjadi di Kecamatan Banyuanyar (Desa Banyuanyar Kidul); Kecamatan Kotaanyar (Desa Sidorejo); Kecamatan Krejengan (Desa Gebangan, Krejengan, dan Rawan); Kecamatan Maron (Desa Sumberdawe); dan Kecamatan Pajarakan (Desa Slogudig Kulon).

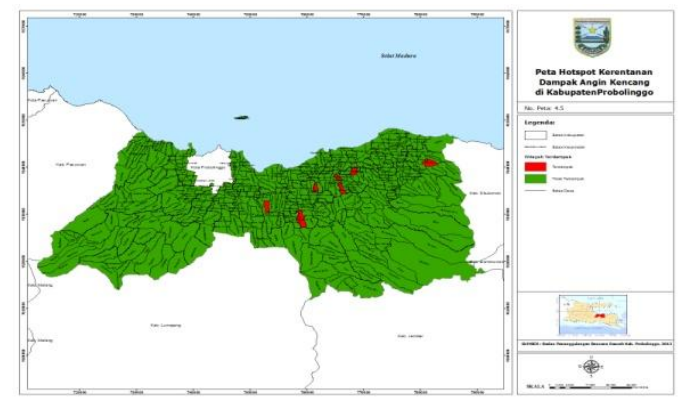

Gambar 5. Pemetaan Dampak Perubahan Iklim Angin Kencang Prioritas 1

\section{Pemetaan Dampak Perubahan Iklim dari Prioritas 2}

Pemetaan dampak perubahan iklim dari prioritas 2, terdiri dari pemetaan dampak dari perubahan iklim, seperti banjir dan chikungunya, dengan wilayah terdampak sebagai berikut.

- Banjir terjadi di Kecamatan Tongas (Desa Bayeman, Tanjungrejo, Tambakrejo, dan Sumendi); Kecamatan Tiris (Desa Segara); Kecamatan Tegalsiwalan (Desa Sumberbulu); Kecamatan Sumberasih (Desa Banjarsari, Lemah Kembar, Lawean, Sumberbendo, Jangur, Ambulu, Muneng, dan Pesisir); Kecamatan Pakuniran (Desa Pakuniran, Ranon, Kedungsumur, dan Gunggungan Lor); Kecamatan Pajarakan (Desa Sukomulyo); Kecamatan Paiton
(Desa Sidodadi dan Jabung Candi); Kecamatan Lumbang (Desa Sapih); Kecamatan Krucil (Desa Plaosan, Tambelang, dan Kalianan); Kecamatan Dringu (Desa Kedungdalem, Dringu, Tegal Rejo, Ngepoh, dan Sumbersuko); Kecamatan Gading (Desa Kaliacar, Batur, Prasi, dan Kertosono); Kecamatan Kraksan (Kelurakan Kraksaan Wetan, Patokan, Sidopekso, dan Sidomukti); Kecamatan Krejengan (Desa Widoro, Kedung Caluk, Dawuhan, dan Gebangan); Kecamatan Besuk (Desa Kecik dan Bago); dan Kecamatan Bantaran (Gunung Tugel).

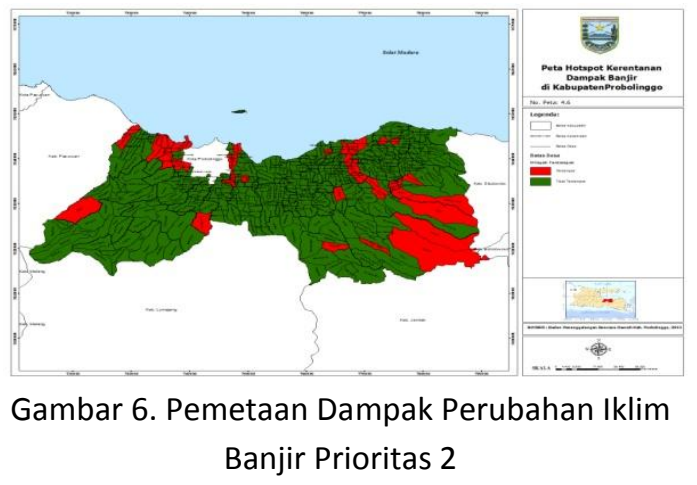

- Chikungunya terjadi di kecamatan daerah pesisir.

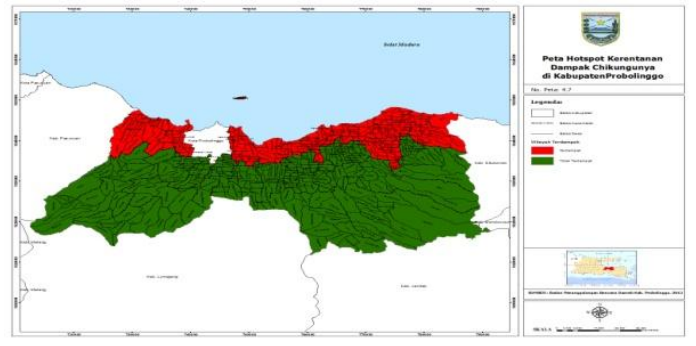

Gambar 7. Pemetaan Dampak Perubahan Iklim Chikungunya Prioritas 2

\section{Pemetaan Dampak Perubahan Iklim dari Prioritas 3}

Pemetaan dampak perubahan iklim dari prioritas 3, terdiri dari pemetaan dampak banjir rob, kekeringan, kekurangan air bersih, dan abrasi pantai.

- Banjir rob terjadi di Kecamatan Dringu (Desa Kalisalam dan Kedungdalem); Kecamatan Gending (Desa Pesisir); Kecamatan Kraksan (Desa Kalibuntu, Asembagus, dan Sidopekso); Kecamatan Paiton (Desa Randu Tatah, Pondo Kelor, dan Randu Merak); Kecamatan Pajarakan 
(Desa Penambangan); Kecamatan Sumberasih (Desa Giliketapang).

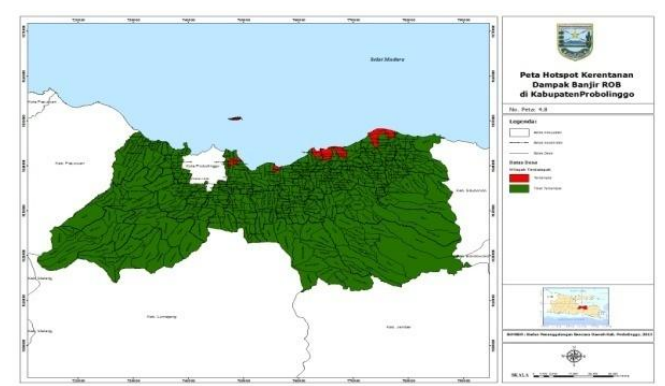

Gambar 8. Pemetaan Dampak Perubahan Iklim Banjir Rob Prioritas 3

- Wilayah terdampak kekeringan sama halnya dengan wilayah kekurangan air bersih karena berdasarkan hasil wawancara dengan BPBD mengatakan bahwa wilayah yang terdampak kekeringan pasti mengalami krisis kekurangan air bersih. Wilayah terdampaknya adalah Kecamatan Wonomerto (Desa Wonorejo dan Sumberkare); Kecamatan Tongas (Desa Curah Tulis, Sumberejo, Wringianom, Pamatan, Klampok, Sumber Kramat, dan Sumendi); Kecamatan Tiris (Desa Jangkang, Racek, dan Tlogosari); Kecamatan Sumber (Desa Rambaan, Sumber, Tukul, Sumberanom, Gemito, Wonokerso); Kecamatan Sumberasih Muneng, dan Sumberbendo); Kecamatan Tegalsiwalan (Desa Blujuran Kidul, Malasan Wetan, Gunung Bekel, dan Tegal Sono); Kecamatan Sukapura (Desa Sukapura dan Ngadirejo); Kecamatan Lumbang (Desa Sapih, Purut, Tandon Sentul, Branggah); Kecamatan Leces (Desa Malasan Kulon, Tigasan Wetan, dan Tigasan Kulon); Kecamatan Kuripan (Desa Jatisari, Wonoasri, Wringinanom, Resongo, dan Kedawung); Kecamatan Krucil (Plaosan, Watu Panjang, dan Betek); Kecamatan Gading (Kertosono dan Ranuwurung); Kecamatan Banyuanyar (Desa Gununggeni dan Leprak Kidul); Kecamatan Bantaran (Desa Legundi, Karanganyar, dan Bantaran).

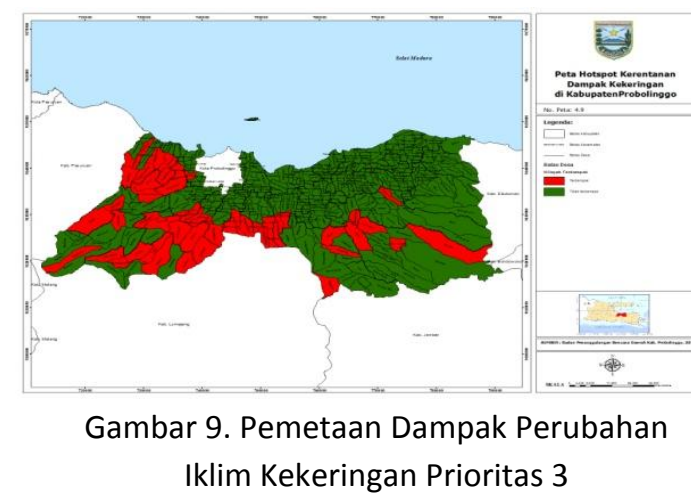

- Abrasi pantai, terjadi di sekitar kawasan pesisir Kabupaten Probolinggo.

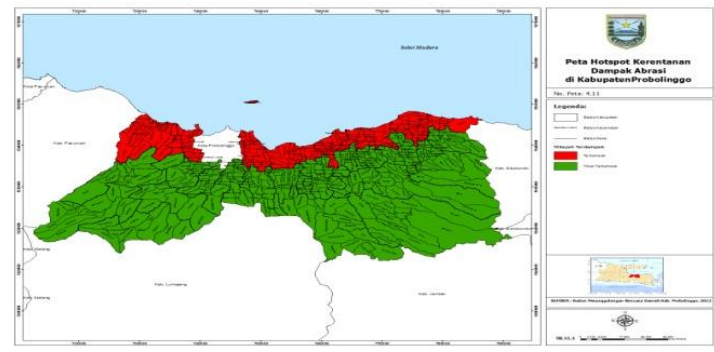

Gambar 10. Pemetaan Dampak Perubahan Iklim Abrasi Pantai Prioritas 3

\section{PEMBAHASAN}

Pemetaan kerentanan risiko iklim diambil dari data sekitar lima tahun terakhir yang terdapat pada arsip SKPD dan instansi daerah lainnya di Kabupaten Probolinggo. Peta kerentanan daerah akibat dampak perubahan iklim ini diharapkan dapat membantu pemerintah daerah untuk mengambil tindakan antisipatif yang dituangkan dalam rencana aksi strategis sehingga dapat meminimalkan kerugian baik nyawa maupun materi.

\section{PENUTUP}

\section{Simpulan}

1. Tindakan terpadu untuk menghadapi perubahan iklim terdiri atas tindakan adaptasi dan mitigasi. 
2. Hasil dari tindakan adaptasi terhadap perubahan iklim adalah pemetaan kerentanan risiko daerah terkena dampak perubahan iklim berdasarkan prioritas tinggi, sedang, dan rendah menggunakan software ArcGIS.

\section{Saran}

Peta kerentanan risiko dampak perubahan iklim selanjutnya dapat digunakan sebagai bahan input dan pedoman bagi penyusunan Rencana Kerja Pemerintah Daerah (RKPD) dan Rencana Pembangunan Jangka Menengah Daerah (RPJMD) untuk memastikan agar di masa mendatang rencana dan program pembangunan semakin responsif terhadap perubahan iklim.

\section{Ucapan Terima Kasih}

Terima kasih kepada Kelompok Kerja Perubahan Iklim Kabupaten Probolinggo, PAKLIM (Program Advis Kebijakan untuk Perlindungan Lingkungan Hidup dan Iklim) GIZ (Deutsche Gesellschaft für Internationale Zusammenarbeit), LPPM ITS, dan tim PSKBPI ITS yang telah banyak membantu dalam kegiatan ini.

\section{DAFTAR PUSTAKA}

Bappenas. 2012. National Action Plan for Climate Change Adaptation (RAN-API) : Synthesis Report.

Comhshaol dan Áitiúl P.A.R. 2012. National Climate Change Adaptation Framework: Building Resilience to Climate Change. Departement of the Environment, Community, and Local Government.

Data primer dan sekunder daerah yang terkena dampak perubahan iklim di Kabupaten Probolinggo. 